\title{
Nitric Oxide, Atrial Natriuretic Peptide, and cyclic GMP Inhibit the Growth-promoting Effects of Norepinephrine in Cardiac Myocytes and Fibroblasts
}

\author{
Angelino Calderone, Cynthia M. Thaik, Nobuyuki Takahashi, Donny L.F. Chang, and Wilson S. Colucci \\ Myocardial Biology Unit and Cardiovascular Division, Departments of Medicine, Boston Medical Center; Boston Veterans Affairs \\ Medical Center; and Boston University School of Medicine, Boston, Massachusetts 02118
}

\begin{abstract}
This study tested the hypothesis that nitric oxide (NO) and atrial natriuretic peptide (ANP) can attenuate the effects of adrenergic agonists on the growth of cardiac myocytes and fibroblasts. In ventricular cells cultured from neonatal rat heart, ANP and the NO donor $S$-nitroso- $N$-acetyl-D,L-penicillamine (SNAP) caused concentration-dependent decreases in the norepinephrine (NE)-stimulated incorporation of $\left[{ }^{3} \mathrm{H}\right]$ leucine in myocytes and $\left[{ }^{3} \mathrm{H}\right]$ thymidine in fibroblasts. In myocytes, the NO synthase inhibitor $N^{\mathrm{G}}$-monomethyl-L-arginine potentiated NE-stimulated $\left[{ }^{3} \mathrm{H}\right]$ leucine incorporation. In both cell types, ANP and SNAP increased intracellular cGMP levels, and their growth-suppressing effects were mimicked by the cGMP analogue 8-bromo-cGMP. Furthermore, in myocytes, 8-bromo-cGMP attenuated the $\alpha_{1}$-adrenergic receptor-stimulated increases in c-fos. Likewise, ANP and 8-bromo-cGMP attenuated the $\alpha_{1}$-adrenergic receptorstimulated increase in prepro-ANP mRNA and the $\alpha_{1}$-adrenergic receptor-stimulated decrease in sarcoplasmic reticulum calcium ATPase mRNA. The L-type $\mathrm{Ca}^{2+}$ channel blockers verapamil and nifedipine inhibited NE-stimulated incorporation of $\left[{ }^{3} \mathrm{H}\right]$ leucine in myocytes and $\left[{ }^{3} \mathrm{H}\right]$ thymidine in fibroblasts, and these effects were not additive with those of ANP, SNAP, or 8-bromo-cGMP. In myocytes, the $\mathrm{Ca}^{2+}$ channel agonist BAY K8644 caused an increase in $\left[{ }^{3} \mathrm{H}\right] \mathrm{leu}-$ cine incorporation which was inhibited by ANP. These findings indicate that NO and ANP can attenuate the effects of NE on the growth of cardiac myocytes and fibroblasts, most likely by a cGMP-mediated inhibition of NE-stimulated $\mathrm{Ca}^{2+}$ influx. (J. Clin. Invest. 1998. 101:812-818.) Key words: nitric oxide - atrial natriuretic peptide - cGMP • cardiac myocytes $\bullet$ cardiac fibroblasts
\end{abstract}

\section{Introduction}

Norepinephrine $(\mathrm{NE})^{1}$ induces myocardial hypertrophy associated with increased protein synthesis by myocytes, the induc-

\footnotetext{
Address correspondence to Dr. Wilson S. Colucci, Boston Medical Center, 88 E. Newton Street, Boston, MA 02118. Phone: 617-6388706; FAX: 617-638-8712; E-mail: wilson.colucci@bmc.org

Received for publication 26 March 1996 and accepted in revised form 17 December 1997.
}

The Journal of Clinical Investigation

Volume 101, Number 4, February 1998, 812-818

http://www.jci.org tion of a fetal gene program, and the development of interstitial fibrosis (1-4). In cultured cardiac myocytes, NE causes myocyte hypertrophy and fetal gene expression primarily via activation of $\alpha_{1}$-adrenergic receptors (2), whereas in cultured cardiac fibroblasts, the induction of DNA synthesis and proliferation by $\mathrm{NE}$ is mediated by $\beta$-adrenergic receptors (5). In both myocytes and fibroblasts, $\mathrm{NE}$, acting via $\alpha_{1}$-adrenergic or $\beta$-adrenergic receptors, respectively, causes the expression of peptide growth factors that can exert autocrine or paracrine effects on growth and gene expression $(4,5)$.

cGMP and substances that increase cellular cGMP, such as natriuretic peptides and nitric oxide (NO)-generating molecules, inhibit the stimulation of DNA synthesis by angiotensin, endothelin, and peptide growth factors in vascular smooth muscle cells, endothelial cells, mesangial cells, and cardiac fibroblasts $(6-9,10)$. There is no information about the effect of cGMP on protein synthesis in cardiac myocytes, or on the ability of cGMP-elevating substances to inhibit the growth-promoting effects of NE in either myocytes or fibroblasts from the heart. However, cardiac myocytes and fibroblasts have receptors for natriuretic peptides $(10,11)$, the myocardium can produce nitric oxide $(12,13)$, and a characteristic of the hypertrophic response is the induction of atrial natriuretic peptide (ANP) in cardiac myocytes $(2,14)$. Taken together, these observations raise the possibility that natriuretic peptides and $\mathrm{NO}$ could attenuate the effects of NE on the growth and phenotype of the myocardium.

Therefore, the primary purpose of this study was to test the hypothesis that cGMP and the cGMP-generating substances NO and ANP inhibit the ability of NE to cause growth of cardiac myocytes and fibroblasts. Our second, related goal was to test the hypothesis that cGMP inhibits the effect of NE on myocyte gene expression. These hypotheses were examined in cultures of neonatal rat cardiac myocytes and fibroblasts by determining the ability of cGMP, ANP, the NO donor $S$-nitroso- $N$-acetyl-D,L-penicillamine (SNAP), and the NO synthase inhibitor $N^{\mathrm{G}}$-monomethyl-L-arginine (L-NMMA) to modulate NE-stimulated protein synthesis and gene expression in myocytes, and DNA synthesis in fibroblasts. Finally, since NE increases $\mathrm{Ca}^{2+}$ influx via L-type $\mathrm{Ca}^{2+}$ channels (15), and cGMP inhibits L-type $\mathrm{Ca}^{2+}$ channels in cardiac myocytes (16-18), our third goal was to examine the possibility that the growth-inhibiting effects of cGMP are mediated via inhibition of $\mathrm{Ca}^{2+}$ influx. 


\section{Methods}

Cultured neonatal rat cardiac myocytes and fibroblasts. Neonatal rat ventricular myocytes were isolated by a modification of the technique of Kasten (19), as described previously (4). Briefly, hearts were removed from 2-d-old neonatal rats anesthetized with ether and killed by decapitation. Ventricular tissues were digested with $0.1 \%$ trypsin (Worthington Biochemical Corp., Freehold, NJ) in HBSS $\left(\mathrm{Ca}^{2+}\right.$ free; GIBCO BRL, Gaithersburg, MD) overnight at $4^{\circ} \mathrm{C}$. Ventricular cells were then recovered by repeated digestions of the tissue in $10 \mathrm{ml}$ of $0.1 \%$ collagenase in HBSS. The supernatants collected from each digestion were centrifuged at $100 \mathrm{~g}$ for $3 \mathrm{~min}\left(4^{\circ} \mathrm{C}\right)$. The pellets were resuspended in ice cold HBSS, pooled, and centrifuged at $100 \mathrm{~g}$ for 4 $\min \left(4^{\circ} \mathrm{C}\right)$. Cells were resuspended in DME containing $7 \%$ heat-inactivated FBS and preplated twice on T80 flasks (Nunc, Inc., Naperville, IL) for 75 min to enrich for myocytes and decrease contamination by nonmuscle cells. The nonadherent myocytes were then plated at a density of 100-200 cells $/ \mathrm{mm}^{2}$ for $\left[{ }^{3} \mathrm{H}\right]$ leucine incorporation (24well plate; Costar Corp., Cambridge, MA) and mRNA studies (100mm plate; Fisher Scientific Co., Pittsburgh, PA). After 24 h, the culture medium was changed to serum-free DME containing insulin (5 $\mu \mathrm{g} / \mathrm{ml})$, transferrin $(5 \mu \mathrm{g} / \mathrm{ml})$, and sodium selenite $(5 \mathrm{ng} / \mathrm{ml})$; all experiments were performed $24 \mathrm{~h}$ later.

Cultures of neonatal rat ventricular nonmyocytes, which have been shown to be predominantly fibroblasts (20), were prepared as described previously by Sadoshima and Izumo (21). Briefly, hearts obtained from neonatal rats were enzyme-digested as described above for myocytes. The adherent nonmyocyte fractions obtained during preplating on T80 flasks were grown in DME containing 7\% FBS until confluent (5-7 d), and passaged with trypsin-EDTA $(0.25 \%, 0.53 \mathrm{mM}$; GIBCO BRL). All experiments were performed on cells from the first or second passages which were placed in serumfree DME containing insulin $(5 \mu \mathrm{g} / \mathrm{ml})$, transferrin $(5 \mu \mathrm{g} / \mathrm{ml})$, and sodium selenite $(5 \mathrm{ng} / \mathrm{ml})$ for $24 \mathrm{~h}$ before the experiment.

$\left[{ }^{3} \mathrm{H}\right]$ leucine and $\left[{ }^{3} \mathrm{H}\right]$ thymidine incorporation. Myocytes and fibroblasts were plated on 24-well plates (Costar Corp.) at a density of $100-200$ cells $/ \mathrm{mm}^{2}$ (myocytes) or $50-100 \mathrm{cells} / \mathrm{mm}^{2}$ (fibroblasts). Protein and DNA synthesis were measured as described previously (21, 22). Briefly, myocytes and fibroblasts were treated with ANP (0.1$100 \mathrm{nM}$; Calbiochem Corp., La Jolla, CA), SNAP (0.1-100 $\mu \mathrm{M}$; Alexis Corp., San Diego, CA), 8-bromo-cGMP (1 mM; Sigma Chemical Co., St. Louis, MO), L-NMMA (1 mM, Sigma Chemical Co.), ( \pm )verapamil (10 $\mu \mathrm{M}$; Sigma Chemical Co.), and/or nifedipine $(1 \mu \mathrm{M}$, Sigma Chemical Co.) for 15-30 min before the addition of 1-norepinephrine (NE; $1 \mu \mathrm{M}$; Sigma Chemical Co.) and either $2.5 \mu \mathrm{Ci} / \mathrm{ml}$ of $\left[{ }^{3} \mathrm{H}\right]$ leucine (DuPont-NEN, Boston, MA) or $2 \mu \mathrm{Ci} / \mathrm{ml}$ of $\left[{ }^{3} \mathrm{H}\right]$ thymidine (DuPont-NEN) for $24 \mathrm{~h}$. Cells were washed twice with $4^{\circ} \mathrm{C}$ PBS, and cold 5\% TCA was added for $30 \mathrm{~min}$ to precipitate protein and DNA. The precipitates were washed twice with cold water and resuspended in $0.4 \mathrm{M} \mathrm{NaOH}$. Aliquots were counted in a scintillation counter.

cGMP production. Myocytes and fibroblasts plated in 6-well plates (Costar Corp.) were pretreated with isobutylmethylxanthine $(0.2 \mathrm{mM})$ for $15 \mathrm{~min}$ before the addition of ANP $(100 \mathrm{nM})$ or SNAP $(100 \mathrm{nM})$, and incubated at $37^{\circ} \mathrm{C}$ for an additional $30 \mathrm{~min}$. The reaction was stopped by the addition of $0.1 \mathrm{M} \mathrm{HCl}$, the plates were placed on ice for $30 \mathrm{~min}$, and the supernatant was collected and titrated to $\mathrm{pH} 7.4$ with $2.5 \mathrm{M}$ sodium acetate (pH 5.8) and $5 \mathrm{M} \mathrm{NaOH.} \mathrm{cGMP}$ levels were quantitated with a standard RIA kit (Biomedical Technologies, Inc., Stoughton, $\mathrm{MA})$. $\mathrm{NaOH}(0.2 \mathrm{M})$ was subsequently added to the plates for $30 \mathrm{~min}$, the cells were scraped, and the protein content was measured by the Bradford technique (Bio-Rad Laboratories, Hercules, CA) with BSA as a standard.

Assessment of $m R N A$ levels. Myocytes were plated at a density of 200 cells $/ \mathrm{mm}^{2}$ in P100 plates (Falcon Labware, Cockeysville, MD). Myocyte mRNA levels were measured as described previously (4). Briefly, myocytes were treated with ANP (100 nM) or 8-bromocGMP (1 mM) for 5-10 min before the addition of $1 \mu \mathrm{M} \mathrm{NE}$ (in the presence of $10 \mu \mathrm{M}$ propranolol) and harvested $30 \mathrm{~min}$ or $24 \mathrm{~h}$ later to examine c-fos and prepro-ANP mRNA levels, respectively. Myocytes were resuspended in denaturing solution (4M guanidium thiocyanate, $25 \mathrm{mM}$ sodium citrate, $0.5 \%$ laurylsarcosine, $0.1 \mathrm{M}$ mercaptoethanol, $\mathrm{pH}$ 7). RNA was denatured with formaldehyde and formamide, and separated by size electrophoresis on a $1.3 \%$ agarose $/ 4 \%$ formaldehyde gel (15 $\mu \mathrm{g}$ total RNA/lane). RNA was transferred to nylon membranes (Genescreen Plus; DuPont-NEN) by vacuum blotting (model 785; Bio-Rad Laboratories) and ultraviolet cross-linked (Stratalinker 1800; Stratagene Inc., La Jolla, CA).

Full-length cDNAs of rat prepro-ANP (courtesy of Dr. C. Seidman, Harvard Medical School) and mouse c-fos (courtesy of Dr. M. Greenberg, Harvard Medical School) were labeled with $\left[{ }^{32} \mathrm{P}\right] \mathrm{dCTP}$ (DuPont-NEN) to a specific activity of $1-2 \times 10^{6} \mathrm{cpm} / \mathrm{ng}$ cDNA by the random hexamer priming method, and hybridized to nylon blots for $18-24 \mathrm{~h}$ at $42^{\circ} \mathrm{C}$. Blots were washed twice (15 min, room temperature) with $300 \mathrm{mM} \mathrm{NaCl} / 30 \mathrm{mM}$ trisodium citrate $(\mathrm{pH} 7)$ and $0.1 \%$ SDS, and twice $\left(15 \mathrm{~min}, 50-55^{\circ} \mathrm{C}\right)$ with $30 \mathrm{mM} \mathrm{NaCl} / 3 \mathrm{mM}$ trisodium citrate (pH 7) and $0.1 \%$ SDS. Blots were exposed to XAR film (Eastman Kodak Co., Rochester, NY) with an intensifying screen at $-70^{\circ} \mathrm{C}$, and films were scanned with a laser densitometer (UltraScan 2202; LKB, Uppsala, Sweden). The sizes of the hybridized messages were estimated using $18 \mathrm{~S}$ and $28 \mathrm{~S}$ rRNA bands as standards. All blots were reprobed with a $\left[{ }^{32} \mathrm{P}\right] \mathrm{ATP}$-labeled oligonucleotide complimentary to $18 \mathrm{~S}$ rRNA (23), and all levels of mRNA reported in this manuscript are normalized to the level of 18S rRNA to correct for potential variations in the amount of RNA loaded or transferred.

\section{Results}

ANP and SNAP attenuate NE-stimulated protein synthesis in myocytes. The addition of NE $(1 \mu \mathrm{M})$ to cultured myocytes for $24 \mathrm{~h}$ caused a $60 \pm 9 \%(P<0.001 ; n=7)$ increase in $\left[{ }^{3} \mathrm{H}\right]$ leucine incorporation (Fig. 1). Preincubation with the $\alpha_{1}$-adrenergic receptor-selective antagonist prazosin $(1 \mu \mathrm{M})$ inhibited this effect of NE by $89 \pm 6 \%(P<0.001 ; n=4)$, confirming that the major effect of $\mathrm{NE}$ on protein synthesis in neonatal rat myocytes plated at low density is mediated by $\alpha_{1}$ -

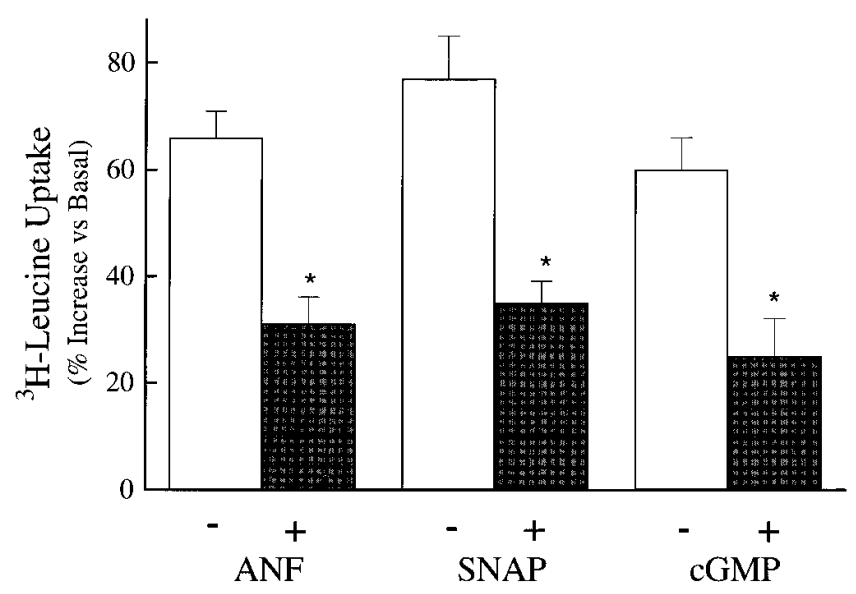

Figure 1. Effects of ANP (ANF), SNAP, and 8-bromo-cGMP on NEstimulated protein synthesis in neonatal rat cardiac myocytes. Myocytes were incubated with NE $(1 \mu \mathrm{M})$ and ANP $(100 \mathrm{nM})$, SNAP $(100 \mu \mathrm{M})$, or 8 -bromo-cGMP $(1 \mathrm{mM})$ for $24 \mathrm{~h}$. Protein synthesis was assessed by measurement of $\left[{ }^{3} \mathrm{H}\right]$ leucine uptake. ANP, SNAP, and 8-bromo-cGMP each inhibited NE-stimulated $\left[{ }^{3} \mathrm{H}\right]$ leucine uptake by $53-57 \%$. ${ }^{*} P<0.002$ vs. basal uptake; $n=15$ (ANP), 6 (SNAP), and 10 (cGMP) experiments, each performed in triplicate. 
A
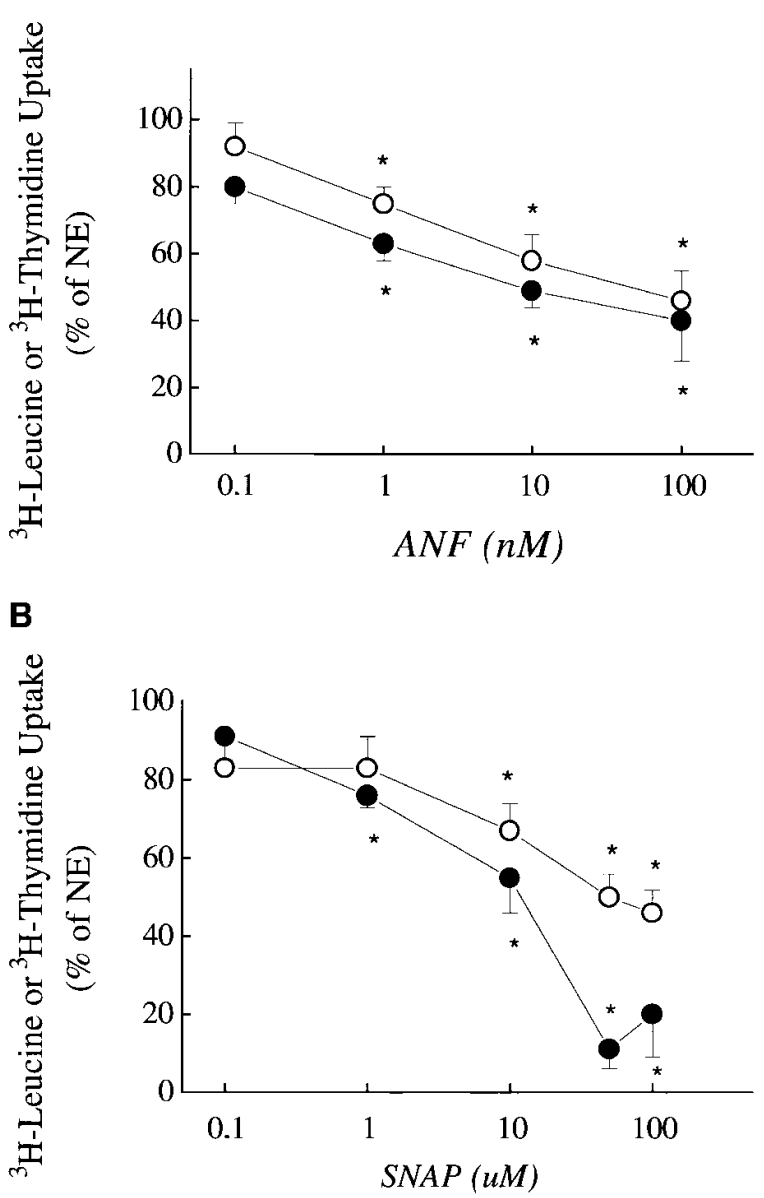

Figure 2. (A) Concentration dependence of ANP $(A N F)$ inhibition of NE-stimulated protein synthesis in neonatal rat cardiac myocytes $(\bigcirc)$ or $\left[{ }^{3} \mathrm{H}\right]$ thymidine uptake in neonatal rat cardiac fibroblasts $(\bullet)$. $(B)$ Concentration dependence of SNAP inhibition of NE-stimulated protein synthesis in neonatal rat cardiac myocytes $(\bigcirc)$ or neonatal rat cardiac fibroblasts $(\bullet) .{ }^{*} P<0.01$ vs. basal uptake; $n=4-6$ experiments, each performed in triplicate.

adrenergic receptors $(1,2)$. The addition of ANP for $24 \mathrm{~h}$ had no effect on basal $\left[{ }^{3} \mathrm{H}\right]$ leucine incorporation, but caused a concentration-dependent inhibition of the NE-stimulated increase (Fig. 2 A). At the highest concentration tested (100 nM), ANP attenuated the NE-mediated increase in $\left[{ }^{3} \mathrm{H}\right]$ leucine incorporation by $53 \pm 7 \%(P=0.001 ; n=15)$ (Fig. 1$)$.

Similarly, addition of the NO-donor SNAP to myocytes for $24 \mathrm{~h}$ had no effect on basal $\left[{ }^{3} \mathrm{H}\right]$ leucine incorporation, but caused a concentration-dependent inhibition of NE-stimulated $\left[{ }^{3} \mathrm{H}\right]$ leucine incorporation (Fig. $2 \mathrm{~B}$ ). At the highest concentration tested $(100 \mu \mathrm{M})$, SNAP attenuated the NE-stimulated increase in $\left[{ }^{3} \mathrm{H}\right]$ leucine incorporation by $53 \pm 6 \%(P=0.001 ; n=$ 6) (Fig. 1).

$N O$ synthase inhibition potentiates $N E$-stimulated protein synthesis in myocytes. The addition of L-NMMA (1 mM) for $24 \mathrm{~h}$ had no effect on basal $\left[{ }^{3} \mathrm{H}\right]$ leucine incorporation in myocytes $(2 \pm 8 \%$ increase vs. basal), but potentiated NE-stimulated $\left[{ }^{3} \mathrm{H}\right]$ leucine incorporation by $44 \pm 5 \%(\mathrm{NE}$ alone, $+76 \pm$ $8 \%$ vs. basal; NE plus L-NMMA, $+109 \pm 13 \%$ vs. basal; $n=6$; $P<0.01$ ) (Fig. 3).
Role of cGMP in mediating the inhibitory effects of ANP and SNAP. In myocytes, the addition of ANP (100 nM) or SNAP $(100 \mu \mathrm{M})$ for $30 \mathrm{~min}$ increased the cellular content of cGMP by two- to threefold (basal, $25 \pm 3 \mathrm{pmol} / \mathrm{mg}$ protein; ANP, $61 \pm 3 \mathrm{pmol} / \mathrm{mg}$ protein; SNAP, $81 \pm 12 \mathrm{pmol} / \mathrm{mg}$ protein; $n=2$ for each), confirming that each is capable of stimulating cGMP production in neonatal cardiac myocytes. To determine whether cGMP can mimic the effects of ANP and SNAP, the cGMP analog 8-bromo-cGMP (1 mM) was added to cultures $15 \mathrm{~min}$ before NE. 8-Bromo-cGMP inhibited NE-stimulated $\left[{ }^{3} \mathrm{H}\right]$ leucine incorporation by $57 \pm 10 \%(P=0.002 ; n=10)$ (Fig. 1). In a separate set of experiments, NE-stimulated $\left[{ }^{3} \mathrm{H}\right]$ leucine incorporation was inhibited $48 \pm 9 \%$ by 8 -bromocGMP, $59 \pm 8 \%$ by ANP, and $54 \pm 9$ by the combination of ANP and cGMP ( $P=\mathrm{NS} ; n=4)$. Thus, the inhibitory effects of 8-bromo-cGMP and ANP were not additive.

The addition of 8-bromo-cGMP for $4 \mathrm{~h}$ followed by a washout immediately before the addition of NE for $24 \mathrm{~h}$ did not attenuate the NE-stimulated increase in $\left[{ }^{3} \mathrm{H}\right]$ leucine incorporation (NE alone, $+61 \pm 24 \%$ vs. basal; NE plus 8 -bromo-cGMP pretreatment, $+81 \pm 34 \%$ vs. basal). Likewise, the addition of 8-bromo-cGMP during only the last $8 \mathrm{~h}$ of a $24 \mathrm{~h}$ exposure to $\mathrm{NE}$ did not inhibit $\left[{ }^{3} \mathrm{H}\right]$ leucine incorporation (NE alone, $+47 \pm 12 \%$ vs. basal; NE plus 8 -bromo-cGMP during last $8 \mathrm{~h}$, $+44 \pm 11 \%$ vs. basal; $P=\mathrm{NS} ; n=5)$. In cardiac myocytes plated at high density $\left(1,000\right.$ cells $\left./ \mathrm{mm}^{2}\right), 8$-bromo-cGMP had no inhibitory effect on NE-stimulated $\left[{ }^{3} \mathrm{H}\right]$ leucine incorporation ( $n=2$; data not shown).

cGMP inhibits the NE-stimulated increase in c-fos $m R N A$ in myocytes. The addition of $\mathrm{NE}(1 \mu \mathrm{M}+10 \mu \mathrm{M}$ propranolol $)$ to myocytes for 30 min caused a marked increase in the level of c-fos mRNA (Fig. $4 A$ ). The addition of 8-bromo-cGMP $(1 \mathrm{mM})$ for $30 \mathrm{~min}$ had no effect on the basal level of c-fos mRNA. However, the addition of 8-bromo-cGMP 15 min before the addition of $\mathrm{NE}$ attenuated the NE-stimulated increase in c-fos mRNA levels by $72 \pm 10 \%(P=0.002 ; n=3)($ Fig. $4 B)$.

cGMP modulates the effects of $N E$ on the levels of preproANP and sarcoplasmic reticulum calcium ATPase (SERCA2) $m R N A$. The addition of NE $(1 \mu \mathrm{M}$ plus $10 \mu \mathrm{M}$ propranolol $)$ to myocytes for $24 \mathrm{~h}$ increased the level of prepro-ANP mRNA 11 \pm 3 -fold $(n=10)$ (Fig. 5, $A$ and $B$ ). The concurrent addition of 8-bromo-cGMP (1 mM) attenuated the NE-stimulated increase by $47 \pm 13 \%(P<0.004$ vs. NE-stimulated; $n=$

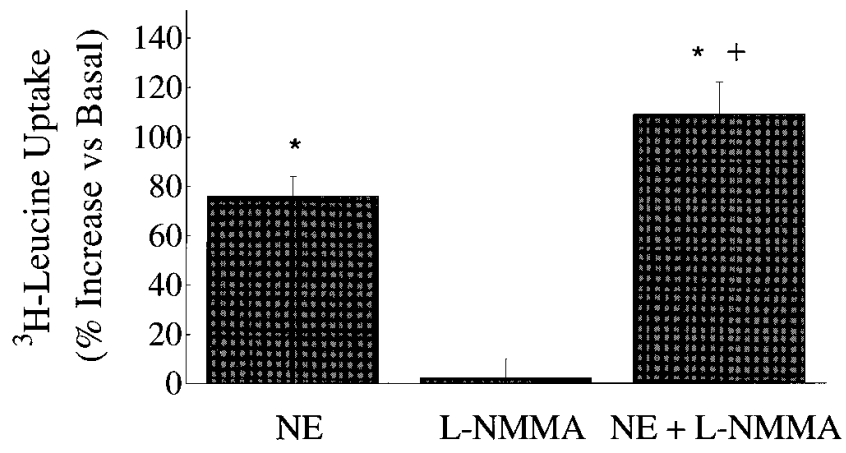

Figure 3. Potentiation of NE-stimulated protein synthesis in myocytes by inhibion of NO synthesis with L-NMMA. $* P<0.01$ vs. basal uptake; ${ }^{+} P<0.014$ vs. NE; $n=6$ experiments, each performed in triplicate. 

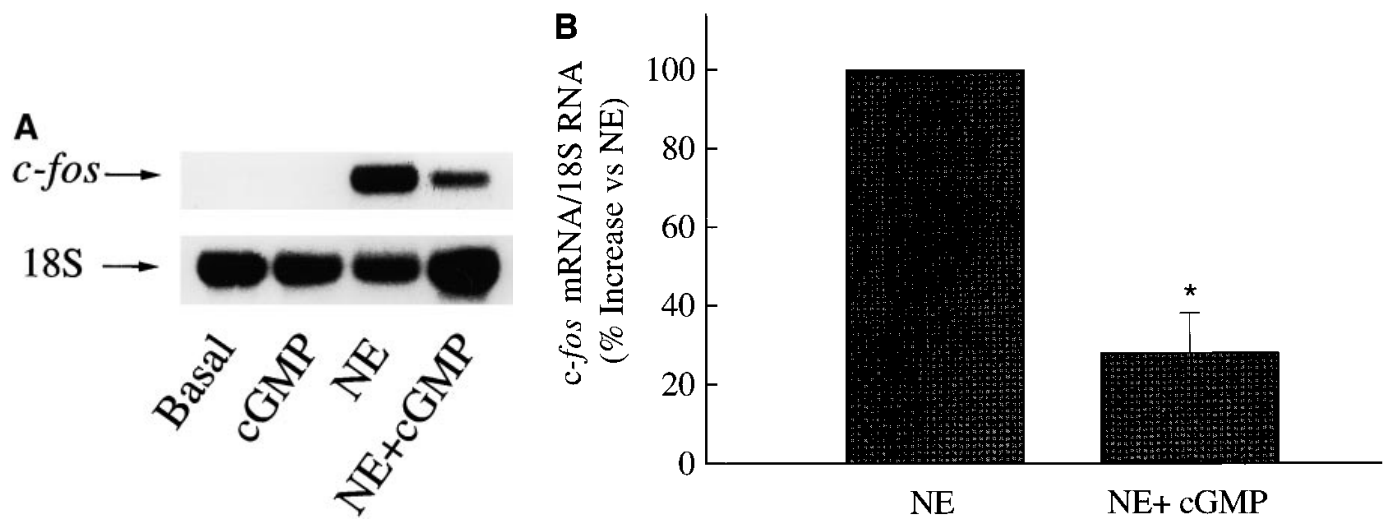

Figure 4. Inhibition of NE-stimulated c-fos mRNA induction by cGMP in neonatal rat cardiac myocytes. $(A)$ Representative Northern hybridization depicting myocytes incubated with 8-bromo-cGMP (1 mM), NE $(1 \mu \mathrm{M})$, or the combination for $30 \mathrm{~min}$. $(B)$ Mean data from three experiments as in $A$. cGMP inhibited the NE-stimulated induction of c-fos mRNA by $72 \pm 10 \%$. $* P<0.002$ vs. NE.

9) compared with cells not exposed to 8-bromo-cGMP (Fig. 5 $B)$. Likewise, the concurrent addition of ANP (100 nM) attenuated the NE-stimulated increase in prepro-ANP mRNA by $42 \pm 4 \%$ compared with myocytes not exposed to ANP $(P=$ 0.002 vs. NE-stimulated; $n=3)$.

The addition of NE ( $1 \mu \mathrm{M}$ plus $10 \mu \mathrm{M}$ propranolol) to myocytes for $24 \mathrm{~h}$ decreased the level of SERCA2 mRNA by $49 \pm 6 \%(n=6)$. The concurrent addition of 8-bromo-cGMP (1 $\mathrm{mM})$ (Fig. $5 \mathrm{~B})$ or ANP $(100 \mathrm{nM})$ for $24 \mathrm{~h}$ attenuated this effect by $60 \pm 17 \%(P<0.01 ; n=6)$ and $60 \%(n=2)$, respectively.

$A N P, N O$, and cGMP inhibit $N E$-stimulated $\left[{ }^{3} H\right]$ thymidine incorporation in cardiac fibroblasts. The addition of NE $(1 \mu \mathrm{M})$ to fibroblasts for $24 \mathrm{~h}$ caused a $63 \pm 9 \%(P<0.001 ; n=8)$ increase in $\left[{ }^{3} \mathrm{H}\right]$ thymidine incorporation (Fig. 6). The addition of propranolol $(10 \mu \mathrm{M})$ inhibited the NE-stimulated increase by $80 \pm 5 \%(12 \pm 3 \%$ increase vs. basal; $P<0.001 ; n=8)$, confirming that under these conditions, NE-stimulated DNA synthesis is mediated predominantly by $\beta$-adrenergic receptors (5).

The addition of ANP (100 nM) had no effect on basal $\left[{ }^{3} \mathrm{H}\right]$ thymidine incorporation in fibroblasts, but the addition of
ANP 30 min before NE caused a concentration-dependent inhibition of NE-stimulated $\left[{ }^{3} \mathrm{H}\right]$ thymidine incorporation (Fig. $2 A)$. At the highest concentration tested, ANP (100 nM) attenuated NE-stimulated $\left[{ }^{3} \mathrm{H}\right]$ thymidine incorporation by $70 \pm$ $8 \%(P<0.001 ; n=11)$ (Fig. 6$)$. The addition of SNAP for $24 \mathrm{~h}$ caused a concentration-dependent decrease in basal $\left[{ }^{3} \mathrm{H}\right]$ thymidine incorporation by $12 \pm 4,25 \pm 4$, and $42 \pm 9 \%(P=0.02$; $n=5$ for all) at 10,50 , and $100 \mu \mathrm{M}$, respectively. The addition of SNAP 15 min before NE $(1 \mu \mathrm{M})$ likewise caused a further concentration-dependent inhibition of NE-stimulated $\left[{ }^{3} \mathrm{H}\right]$ thymidine incorporation (Fig. $2 \mathrm{~B}$ ). At the highest concentration tested, SNAP $(100 \mu \mathrm{M})$ attenuated the NE-stimulated increase in $\left[{ }^{3} \mathrm{H}\right]$ thymidine incorporation by $80 \pm 11 \%(P=0.001$ vs. SNAP alone; $n=4$ ) (Fig. 6).

Role of cGMP in mediating the effects of ANP and NO in fibroblasts. ANP $(100 \mathrm{nM})$ and SNAP $(100 \mu \mathrm{M})$ increased cellular cGMP content in fibroblasts by $\sim 5$ - and 50-fold, respectively (basal, $51 \pm 9 \mathrm{pmol} / \mathrm{mg}$ protein $/ 30 \mathrm{~min}$; ANP, 240 \pm 6 $\mathrm{pmol} / \mathrm{mg}$ protein $/ 30 \mathrm{~min}$; SNAP, $2,700 \pm 150 \mathrm{pmol} / \mathrm{mg}$ protein/30 $\min ; n=2$ each). The addition of the cGMP analogue 8-bromo-cGMP (1 $\mathrm{mM})$ alone for $24 \mathrm{~h}$ decreased basal

\section{A}

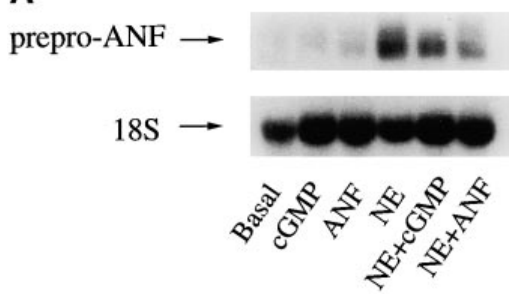

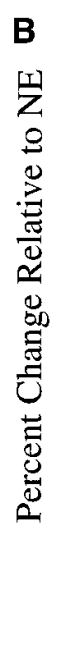

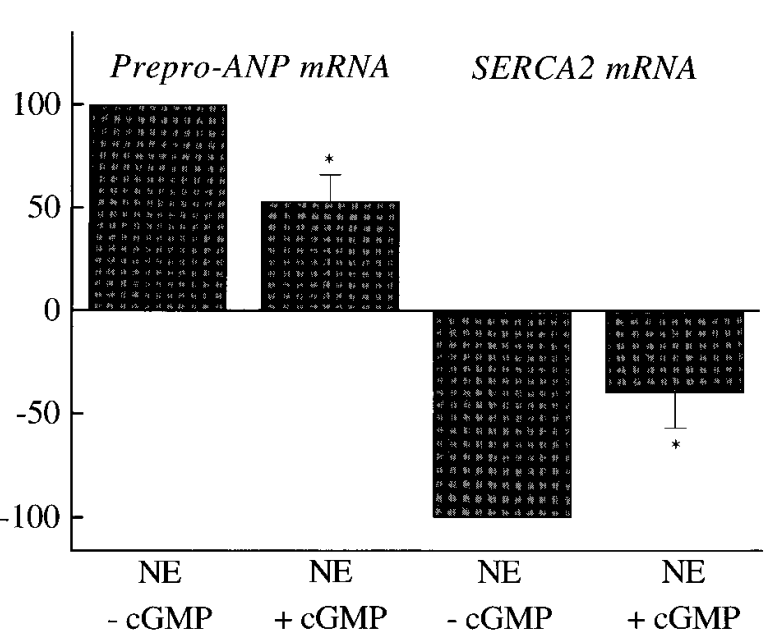

Figure 5. (A) Inhibition of NE-stimulated prepro-ANP $(A N F)$ mRNA induction in neonatal rat cardiac myocytes by 8-bromo-cGMP and ANP $(A N F)$. Northern hybridization showing the effects of a $24 \mathrm{~h}$ incubation with 8-bromo-cGMP (1 $\mathrm{mM})$, ANP (100 $\mathrm{nM})$, and $\mathrm{NE}(1 \mu \mathrm{M})$, alone and in combination, on the expression of prepro-ANP mRNA. (B) Average effects of cGMP $(1 \mathrm{mM})$ on the regulation of preproANP and SERCA2 mRNA by NE. Cells were

incubated for $24 \mathrm{~h}$ with $\mathrm{NE}$ alone or in combination with 8-bromo-cGMP $(c G M P)$. Data are presented as the percentage of the effect caused by NE alone. Depicted are the means of nine (ANP) or six (SERCA2) experiments. $* P<0.01$ vs. NE alone. 


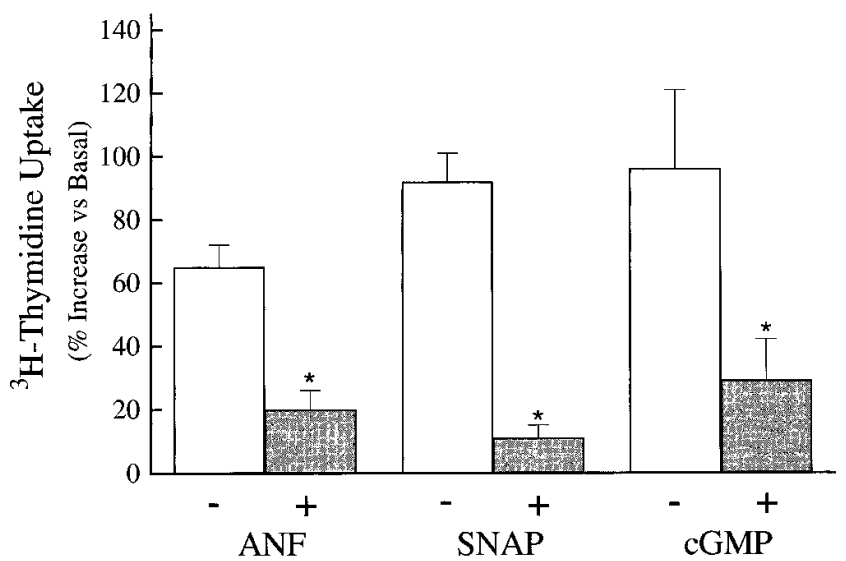

Figure 6. Inhibition of NE-stimulated DNA synthesis in neonatal rat cardiac myocytes by ANP $(A N F)$, SNAP, and 8-bromo-cGMP. Fibroblasts were incubated with NE $(1 \mu \mathrm{M})$ and ANP $(100 \mathrm{nM})$, SNAP $(100 \mu \mathrm{M})$, or cGMP $(1 \mathrm{mM})$ for $24 \mathrm{~h}$. DNA synthesis was assessed by the uptake of $\left[{ }^{3} \mathrm{H}\right]$ thymidine. ${ }^{*} P<0.001$ vs. basal uptake. Depicted are the mean data from 11 (ANP), 4 (SNAP), and 5 (cGMP) experiments, each performed in triplicate.

$\left[{ }^{3} \mathrm{H}\right]$ thymidine incorporation by $35 \pm 4 \%(P<0.01 ; n=7)$. The addition of 8-bromo-cGMP 15 min before NE further inhibited the NE-stimulated increase in $\left[{ }^{3} \mathrm{H}\right]$ thymidine incorporation by $77 \pm 7 \%(P=0.001$ vs. 8 -bromo-cGMP alone; $n=5)$ (Fig. 6).

Role of calcium influx in mediating the growth effects of cGMP, ANP, and NO in myocytes and fibroblasts. The addition of the L-type $\mathrm{Ca}^{2+}$ channel agonist BAY K8644 $(1 \mu \mathrm{M})$ to myocytes for $24 \mathrm{~h}$ increased $\left[{ }^{3} \mathrm{H}\right]$ leucine incorporation by $28 \pm 6 \%(n=5 ; P=0.01)$. The addition of ANP $(100 \mathrm{nM})$ inhibited BAY K8644-stimulated [ $\left.{ }^{3} \mathrm{H}\right]$ leucine incorporation by $70 \pm 8 \%(n=5 ; P=0.014)$. The addition of the L-type calcium channel inhibitors verapamil $(10 \mu \mathrm{M})$ and nifedipine $(10 \mu \mathrm{M})$ had no effect on basal $\left[{ }^{3} \mathrm{H}\right]$ leucine incorporation, but attenuated markedly the NE-stimulated increase, by $61 \pm 5 \%(P<$ $0.001 ; n=19)($ Fig. $7 A)$ and $63 \pm 4 \%(P<0.01 ; n=3)$, respectively. The inhibition of NE-stimulated $\left[{ }^{3} \mathrm{H}\right]$ leucine incorporation by verapamil was not additive with that caused by ANP $(100 \mathrm{nM})$ (Fig. 7 B), SNAP $(100 \mu \mathrm{M})$, or 8-bromo-cGMP (1 $\mathrm{mM})$ (data not shown).

In fibroblasts, the addition of verapamil for $24 \mathrm{~h}$ decreased basal $\left[{ }^{3} \mathrm{H}\right]$ thymidine incorporation by $35 \pm 5 \%(P=0.05 ; n=$ $6)$. The addition of verapamil or nifedipine $30 \mathrm{~min}$ before NE inhibited NE-stimulated $\left[{ }^{3} \mathrm{H}\right]$ thymidine incorporation by $84 \pm 4 \%(P<0.001$ vs. verapamil alone; $n=12$; Fig. $7 A)$ and $65 \pm 9 \%(P<0.002$ vs. nifedipine alone; $n=3)$, respectively.

\section{Discussion}

The major new finding of this study is that ANP and NO exerted an antiadrenergic action by inhibiting the growth-promoting effects of NE in both cardiac myocytes and fibroblasts. NE stimulated protein synthesis in cardiac myocytes via activation of $\alpha_{1}$-adrenergic receptors and stimulated DNA synthesis in cardiac fibroblasts via activation of $\beta$-adrenergic receptors. Both effects of NE were attenuated by ANP and NO. Con- versely, inhibition of endogenous $\mathrm{NO}$ synthesis potentiated the magnitude of NE-stimulated protein synthesis. ANP and $\mathrm{NO}$ were coupled to the generation of cGMP in cardiac myocytes and fibroblasts, and cGMP mimicked the effects of ANP and $\mathrm{NO}$ in both cell types, suggesting that the growth-inhibiting effects of ANP and NO are mediated, at least in part, by cGMP. Consistent with these observations, we found that cGMP inhibited the reciprocal NE-stimulated changes in prepro-ANP (increase) and SERCA2 (decrease) mRNA levels that are characteristic of hypertrophied myocardium $(24,25)$. cGMP also attenuated the NE-stimulated induction of c-fos mRNA, indicating that its growth-inhibiting action may be mediated, at least in part, by inhibition of one or more early response genes.

There is precedent for a growth-inhibiting effect of cGMP and cGMP-generating compounds in vascular smooth muscle cells and cardiac fibroblasts. In vascular smooth muscle cells,
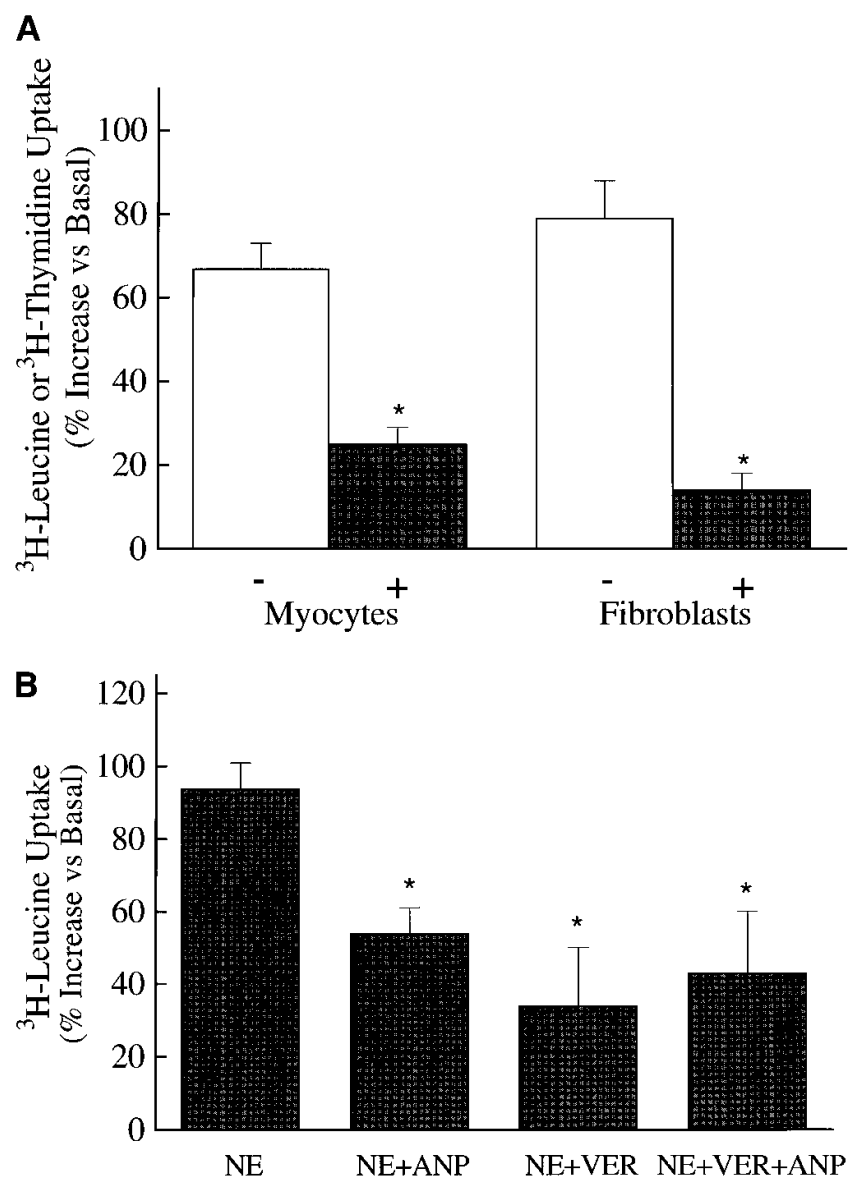

Figure 7. Effects of verapamil on NE-stimulated protein synthesis in neonatal rat cardiac myocytes and fibroblasts. $(A)$ Verapamil inhibited NE-stimulated protein synthesis in myocytes and NE-stimulated DNA synthesis in fibroblasts. Cells were incubated with NE (white bars) or NE plus $10 \mu \mathrm{M}$ verapamil (black bars) for $24 \mathrm{~h}$. $* P<0.01$ vs. $\mathrm{NE}$ alone. Depicted are the mean data from 19 experiments, each performed in triplicate. $(B)$ Effects of a 24-h incubation with verapamil $(V E R ; 10 \mu \mathrm{M})$, ANP $(100 \mathrm{nM})$, and the combination, on NEstimulated protein synthesis in neonatal rat cardiac myocytes. The combination of ANP plus verapamil had no greater effect than ANP or verapamil alone. $* P<0.001$ vs. basal. Depicted are the mean data from three experiments, each performed in triplicate. 
ANP, NO, and cGMP can inhibit serum-, epidermal growth factor-, or angiotensin-stimulated DNA synthesis and proliferation $(6,8,10)$. NO has also been shown to inhibit serum-stimulated protein and collagen synthesis in vascular smooth muscle cells (26). In fibroblasts from neonatal rat heart, Long et al. (5) have shown that adrenergic agonists induce DNA synthesis via $\beta$-rather than $\alpha_{1}$-adrenergic receptors, which are not expressed in this cell type (27). Our data indicate that in cardiac fibroblasts, $\beta$-adrenergic receptor-stimulated DNA synthesis is inhibited by ANP, NO, and cGMP. Recently, Cao and Gardner (9) have shown that ANP, NO, and cGMP inhibit peptide growth factor-, angiotensin-, and endothelin-stimulated DNA synthesis in cardiac fibroblasts. Therefore, our observations in cardiac fibroblasts extend the growth-inhibiting effect of cGMP-generating compounds to the $\beta$-adrenergic signaling pathway, and together with the findings in cardiac myocytes, provide the first evidence that cGMP-generating compounds exert an antiadrenergic effect on the hypertrophic actions of $\mathrm{NE}$ in the myocardium.

These data add to the known physiologic actions of ANP, NO, and cGMP in the myocardium. ANP acts via three receptor subtypes, termed A, B, and C, all of which have been identified in adult rat myocardium (28), and cardiac myocytes and fibroblasts isolated from adult rat heart (11). In neonatal rat cardiac myocytes, ANP inhibits both the amplitude of spontaneous contractions and $\mathrm{Ca}^{2+}$ influx (29). Likewise, NO, which couples to the generation of cGMP, can exert a direct negative inotropic effect on the myocardium (30). Further, it has been shown that cGMP and NO can inhibit the contractile responses to both $\alpha_{1}$ - and $\beta$-adrenergic receptor stimulation (13, 31). It has been suggested that the negative inotropic effects of cGMP, ANP, and $\mathrm{NO}$ are due to inhibition of $\mathrm{Ca}^{2+}$ influx via the L-type $\mathrm{Ca}^{2+}$ channel $(16,17)$. In contrast to amphibian cells, in which this effect is due to activation of a phosphodiesterase with a resultant decrease in cAMP, in mammalian cells, the effect of cGMP to inhibit $\mathrm{Ca}^{2+}$ influx does not depend on changes in cAMP, but rather appears to reflect a direct effect on the channel (16-18).

Our data suggest that the growth-inhibiting effects of cGMP, ANP, and NO in cardiac myocytes and fibroblasts were mediated in part by the inhibition of $\mathrm{Ca}^{2+}$ influx. First, in myocytes, protein synthesis stimulated by the $\mathrm{Ca}^{2+}$ channel agonist BAY K8644 was inhibited by ANP. Second, the growthinhibiting effects of ANP and NO were mimicked both qualitatively and quantitatively by the $\mathrm{Ca}^{2+}$ channel antagonists verapamil and nifedipine. Finally, the effects of verapamil and nifedipine were not additive with those of ANP, NO, or cGMP in myocytes or fibroblasts.

The role of $\mathrm{Ca}^{2+}$ influx in mediating the myocyte growth response to $\mathrm{NE}$ is not clearly established, in part due to the technical difficulty of dissociating direct effects of $\mathrm{Ca}^{2+}$ from indirect effects due to cellular contraction (32). However, in neonatal rat cardiac myocytes, NE causes cellular growth and induction of prepro-ANP mRNA primarily via activation of $\alpha_{1}$-adrenergic receptors of the pharmacological A subtype (2), which are coupled to an increase in L-type $\mathrm{Ca}^{2+}$ channel current in cardiac myocytes (15). Likewise, it has been shown that $\mathrm{Ca}^{2+}$ influx is essential for the $\alpha_{1}$-adrenergic receptor-stimulated induction of prepro-ANP mRNA (14). In cardiac fibroblasts, $\beta$-adrenergic receptor stimulation, presumably acting via cAMP, also increases the L-type $\mathrm{Ca}^{2+}$ channel current (33). Booz et al. (34) observed that angiotensin-stimulated DNA synthesis is mediated, at least in part, via a $\mathrm{Ca}^{2+}$-dependent pathway in neonatal rat cardiac fibroblasts.

Since myocytes exhibit spontaneous contractions under the conditions of these experiments, we cannot determine whether the growth-inhibiting effects we observed were due to a direct decrease in intracellular $\mathrm{Ca}^{2+}$ or an indirect effect of reduced contractions. However, since fibroblasts do not contract spontaneously under these conditions, we can conclude that in these cells, the growth-promoting effect of $\mathrm{Ca}^{2+}$ influx is not related to contraction, and most likely reflects a direct biochemical action. We cannot exclude a role for non-cGMPmediated effects of ANP or NO. In cardiac fibroblasts, ANP inhibition of serum-stimulated DNA synthesis appears to be mediated not only by the A and B subtypes, but also by the $\mathrm{C}$ subtype (9), which is not coupled to cGMP, and there is evidence for an antimitogenic effect of the $\mathrm{C}$ subtype in rat aortic smooth muscle and glial cells $(35,36)$.

Recently, Zheng et al. (37) observed that ATP inhibits hypertrophy stimulated by NE, basic fibroblast growth factor, and endothelin- 1 in neonatal cardiac myocytes. It is noteworthy that the effects of ATP and cGMP on $\alpha_{1}$-adrenergic receptor-stimulated hypertrophy differ in several ways. First, they exhibit markedly different temporal requirements. Whereas a transient preexposure to ATP inhibits the subsequent ability of $\alpha_{1}$-adrenergic receptor stimulation to cause hypertrophy, cGMP must be present continuously with NE to exert its inhibitory action. Second, whereas ATP itself stimulates c-fos mRNA and does not inhibit the stimulation by NE, cGMP has no effect by itself and inhibits markedly the stimulation caused by NE. Third, cGMP but not ATP inhibits the ability of NE to downregulate the level of SERCA2 mRNA. These differences suggest that the two nucleotides inhibit $\alpha_{1}$-adrenergic receptor-stimulated myocyte growth by distinct mechanisms.

In contrast to our findings, Harding et al. (38) found that phenylephrine-stimulated protein synthesis in neonatal rat cardiac myocytes was not inhibited by cGMP. Of note, we have found that the inhibitory effect of cGMP is absent in cells cultured at high density $\left(1,000 \mathrm{cell} / \mathrm{mm}^{2}\right)$, suggesting that this discrepancy may reflect our use of low density (100-200 cells/ $\mathrm{mm}^{2}$ ) cultures as opposed to the high density $\left(1,000 \mathrm{cells} / \mathrm{mm}^{2}\right)$ cultures used by Harding et al. (38). This thesis is supported by evidence that cell density can exert qualitative effects on the pathways that mediate NE-stimulated protein synthesis in neonatal rat cardiac myocytes (39).

The implications of these findings remain to be demonstrated. However, they raise the possibility that NO, ANP, and other cGMP-generating compounds could attenuate the effects of NE on the growth and phenotype of the myocardium. Such antiadrenergic actions might play an adaptive, counterregulatory role by acting in an autocrine or paracrine manner to limit the adverse effects (e.g., interstitial fibrosis and fetal gene induction) of increased sympathetic tone on the myocardium. This thesis is supported by a recent report from $\mathrm{Wu}$ et al. (40) that ANP stimulates apoptosis in neonatal rat cardiac myocytes and that this effect is abolished by norepinephrine, which by itself has no affect on apoptosis in this system.

Although ANP expression is minimal or absent in normal ventricular myocardium, several hypertrophic stimuli induce natriuretic peptides (23). Furthermore, expression of constitutive NO synthase (NOS3) and NO production are present in cardiac myocytes (13), and cardiac NO production may be increased due to induction of inducible NO synthase (NOS2) 
in pathological states such as myocardial failure (41). Our finding that inhibition of NO synthesis by L-NMMA potentiated NE-stimulated protein synthesis in myocytes suggests that basal levels of endogenous NO production could modulate myocyte growth. Consistent with this view, myocardial hypertrophy and fetal gene expression were attenuated by chronic administration of the NO precursor L-arginine in the spontaneously hypertensive rat (42). Conversely, it is possible that excessive activation of ANP, NO, and other cGMP-generating pathways could be maladaptive by suppressing the requisite myocardial response to adrenergic or other hypertrophic stimuli. Understanding the physiologic and pathophysiologic effects of NO, natriuretic peptides, and other cGMP-generating compounds in the myocardium may allow the development of new strategies for modulating the growth and phenotype of the myocardium.

\section{References}

1. Simpson, P.C. 1983. Norepinephrine-stimulated hypertrophy of cultured rat myocardial cells is an alpha ${ }_{1}$ adrenergic response. J. Clin. Invest. 72:732-738.

2. Knowlton, K.U., M.C. Michel, M. Itani, H.E. Shubeita, K. Ishihara, J.H. Brown, and K.R. Chien. 1993. The alpha- ${ }_{1 \mathrm{~A}}$-adrenergic receptor subtype mediates biochemical, molecular, and morphologic features of cultured myocardial cell hypertrophy. J. Biol. Chem. 268:15374-15380.

3. Bhambi, B., and M. Eghbali. 1991. Effect of norepinephrine on myocardial collagen gene expression and response of cardiac fibroblasts after norepinephrine treatment. Am. J. Pathol. 139:1131-1142.

4. Takahashi, N., A. Calderone, N.J. Izzo, Jr., T.M. Maki, J.D. Marsh, and W.S. Colucci. 1994. Hypertrophic stimuli induce transforming growth factorbeta $_{1}$ expression in rat ventricular myocytes. J. Clin. Invest. 94:1470-1476.

5. Long, C.S., W.E. Hartogenesis, and P.C. Simpson. 1993. Beta-adrenergic stimulation of cardiac non-myocytes augments the growth-promoting activity of non-myocyte conditioned medium. J. Mol. Cell. Cardiol. 25:915-925.

6. Garg, U.C., and A. Hassid. 1989. Nitric oxide-generating vasodilators and 8-bromo-cyclic guanosine monophosphate inhibit mitogenesis and proliferation of cultured rat vascular smooth muscle cells. J. Clin. Invest. 83:1774-1777.

7. Kohno, M., M. Ikeda, M. Johchi, T. Horio, K. Yasunari, N. Kurihara, and T. Takeda. 1993. Interaction of PDGF and natriuretic peptides on mesangial cell proliferation and endothelin secretion. Am. J. Physiol. 265:E673-E679.

8. Morishita, R., G.H. Gibbons, R.E. Pratt, N. Tomita, Y. Kaneda, T. Ogihara, and V.J. Dzau. 1994. Autocrine and paracrine effects of atrial natriuretic peptide gene transfer on vascular smooth muscle and endothelial cellular growth. J. Clin. Invest. 94:824-829.

9. Cao, L., and D.G. Gardner. 1995. Natriuretic peptides inhibit DNA synthesis in cardiac fibroblasts. Hypertension (Dallas). 25:227-234.

10. Yu, S.-M., L.-M. Hung, and C.-C. Lin. 1997. cGMP-elevating agents suppress proliferation of vascular smooth muscle cells by inhibiting the activation of epidermal growth factor signaling pathway. Circulation. 95:1269-1277.

11. Lin, X., J. Hanze, F. Heese, R. Sodmann, and R.E. Lang. 1995. Gene expression of natriuretic peptide receptors in myocardial cells. Circ. Res. 77:750-758.

12. Schulz, R., E. Nava, and S. Moncada. 1992. Induction and potential biological relevance of a $\mathrm{Ca}^{2+}$-independent nitric oxide synthase in the myocardium. Br. J. Pharmacol. 105:575-580.

13. Balligand, J.-L., R.A. Kelly, P.A. Marsden, T.W. Smith, and T. Michel. 1993. Control of cardiac muscle cell function by an endogenous nitric oxide signaling system. Proc. Natl. Acad. Sci. USA. 90:347-351.

14. Sei, C.A., C.E. Irons, A.B. Sprenkle, P.M. McDonough, J.H. Brown, and C.C. Glembotski. 1991. The alpha-adrenergic stimulation of atrial natriuretic factor expression in cardiac myocytes requires calcium influx, protein kinase C, and calmodulin-regulated pathways. J. Biol. Chem. 266:15910-15916.

15. Liu, Q., E. Karpinski, and P.K.T. Pang. 1994. The L-type calcium channel is increased by alpha-1 adrenoceptor activation in neonatal rat ventricular cells. J. Pharmacol. Exp. Ther. 271:935-943.

16. Mery, P.-F., S.M. Lohmann, U. Walter, and R. Fischmeister. 1991. Ca ${ }^{2+}$ current is regulated by cyclic GMP-dependent protein kinase in mammalian cardiac myocytes. Proc. Natl. Acad. Sci. USA. 88:1197-1201.

17. Wahler, G.M., and S.J. Dollinger. 1995. Nitric oxide donor SIN-1 inhibits mammalian cardiac calcium current through cGMP-dependent protein ki- nase. Am. J. Physiol. 268:C45-C54.

18. Tohse, N., H. Nakaya, Y. Takeda, and M. Kano. 1995. Cyclic GMPmediated inhibition of L-type $\mathrm{Ca}^{++}$channel by the human natriuretic peptide in rabbit heart cells. Br. J. Pharmacol. 114:1076-1082.

19. Kasten, F.H. 1973. In Tissue Culture Methods and Applications. P.F. Kruse, Jr., and M.K. Patterson, Jr., editors. Academic Press, Inc., New York. $72-86$.

20. Schorb, W., G.W. Booz, D.E. Dostal, K.M. Conrad, K.C. Chang, and K.M. Baker. 1993. Angiotensin II is mitogenic in neonatal rat cardiac fibroblasts. Circ. Res. 72:1245-1254.

21. Sadoshima, J., and S. Izumo. 1993. Molecular characterization of angiotensin II-induced hypertrophy of cardiac myocytes and hyperplasia of cardiac fibroblasts. Critical role of the $\mathrm{AT}_{1}$ receptor subtype. Circ. Res. 73:413-423.

22. Thaik, C.M., A. Calderone, N. Takahashi, and W.S. Colucci. 1995. Interleukin-1 $\beta$ modulates the growth and phenotype of neonatal rat cardiac myocytes. J. Clin. Invest. 96:1093-1099.

23. Izzo, N.J., Jr., C.E. Seidman, S. Collins, and W.S. Colucci. 1990. Alpha ${ }_{1-}$ adrenergic receptor mRNA level is regulated by norepinephrine in rabbit aortic smooth muscle cells. Proc. Natl. Acad. Sci. USA. 87:6268-6271.

24. Knowlton, K.U., H.A. Rockman, M. Itani, A. Vovan, C.E. Seidman, and K.R. Chien. 1995. Divergent pathways mediate the induction of ANF transgenes in neonatal and hypertrophic ventricular myocardium. J. Clin. Invest. 96: 1311-1318.

25. Calderone, A., N. Takahashi, N.J. Izzo, Jr., and W.S. Colucci. Pressureand volume-induced left ventricular hypertrophies are associated with distinct myocyte phenotypes and differential induction of peptide growth factor mRNAs. 1995. Circulation. 92:2385-2390.

26. Kolpakov, V., D. Gordon, and T.J. Kulik. 1995. Nitric oxide-generating compounds inhibit total protein and collagen synthesis in cultured vascular smooth muscle cells. Circ. Res. 76:305-309.

27. Stewart, A.F.R., G. Rokosh, B.A. Bailey, L.R. Karns, K.C. Chany, C.S Long, K.-I. Kariya, and P.C. Simpson. 1994. Cloning of the rat alpha-1C-adrenergic receptor from cardiac myocytes. Circ. Res. 75:796-802.

28. Nunez, D.J.R., M.C. Dickson, and M.J. Brown. 1992. Natriuretic peptide receptor mRNAs in the rat and human heart. J. Clin. Invest. 90:1966-1971.

29. McCall, D., and T.A. Freid. 1990. Effect of atriopeptin II on Ca influx, contractile behavior and cyclic nucleotide content of cultured neonatal rat myocardial cells. J. Mol. Cell. Cardiol. 22:201-212.

30. Brady, A.J., J.B. Warren, P.A. Poole-Wilson, T.J. Williams, and S.E. Harding. 1993. Nitric oxide attenuates cardiac myocyte contraction. Am. J. Physiol. 265:H176-H186.

31. Evans, H.G., A.M. Shah, and M.J. Lewis. 1992. Cyclic GMP inhibits the inotropic response to $\alpha_{1}$-adrenoceptors in the papillary muscle of the ferret. Cardioscience. 3:257-264.

32. Qi, M., K. Ojamaa, E.G. Eleftheriades, I. Klein, and A.M. Samarel. 1994. Regulation of rat ventricular myosin heavy chain expression by serum and contractile activity. Am. J. Physiol. 36:C520-C528.

33. Iizuka, K., H. Sano, H. Kawaguchi, and A. Kitabatake. 1994. Transforming growth factor beta-1 modulates the number of beta-adrenergic receptors in cardiac fibroblasts. J. Mol. Cell. Cardiol. 26:435-440.

34. Booz, G.W., D.E. Dostal, H.A. Singer, and K.M. Baker. 1994. Involvement of protein kinase $\mathrm{C}$ and $\mathrm{Ca}^{2+}$ in angiotensin II-induced mitogenesis of cardiac fibroblasts. Am. J. Physiol. 267:C1308-C1318.

35. Cahill, P.A., and A. Hassid. 1991. Clearance receptor-binding atrial natriuretic peptides inhibit mitogenesis and proliferation of rat aortic smooth muscle cells. Biochem. Biophys. Res. Comm. 179:1606-1613.

36. Levin, E.R., and H.S.L. Frank. 1991. Natriuretic peptides inhibit rat astroglial proliferation: mediation by C receptor. Am. J. Physiol. 261:R453-R457.

37. Zheng, J.-S., M.O. Boluyt, X. Long, L. O'Neill, E.G. Lakatta, and M.T. Crow. 1996. Extracellular ATP inhibits adrenergic agonist-induced hypertrophy of neonatal cardiac myocytes. J. Clin. Invest. 78:525-535.

38. Harding, P., O.A. Carretero, and M.C. LaPointe. 1995. Effects of interleukin-1 $\beta$ and nitric oxide on cardiac myocytes. Hypertension (Dallas). 25:421-430.

39. Bishopric, N.H., and L. Kedes. 1991. Adrenergic regulation of the skeletal alpha-actin gene promoter during myocardial cell hypertrophy. Proc. Natl. Acad. Sci. USA. 88:2132-2136.

40. Wu, C.-F., N.H. Bishopric, and R.E. Pratt. 1997. Atrial natriuretic peptide induces apoptosis in neonatal rat cardiac myocytes. J. Biol. Chem. 272: 14860-14866.

41. Haywood, G.A., P.S. Tsao, H.E. von der Leyen, M.J. Mann, P.J. Keeling, P.T. Trindade, N.P. Lewis, C.D. Byrne, P.R. Rickenbacher, N.H. Bishopric et al. 1996. Expression of inducible nitric oxide synthase in human heart failure. Circulation. 93:1087-1094.

42. Matsuoka, H., M. Nakata, K. Kohn, Y. Kogo, G. Nomura, H. Toshima, and T. Imaizumi. 1996. Chronic L-arginine administration attenuates cardiac hypertrophy in spontaneously hypertensive rats. Hypertension (Dallas). 27:14-18. 